\title{
PENGARUH GAYA KEPEMIMPINAN, EMPATI DAN MOTIVASI TERHADAP BUDAYA ORGANISASI (Studi Kasus Terhadap Kepala Sekolah Dasar Kota Gorontalo)
}

\author{
Novianty Djafri \\ Fakultas Ilmu Pendidikan Universitas Negeri Gorontalo \\ Email: noviantydjafri@yahoo.com
}

\begin{abstract}
Purpose of the study to determine the effect of leadership style, empathy, and motivation of on the organization culture as the principal basis of Gorontalo city. The study object is the subject of elementary school principals as many as 55 people. Four variables of the data gathered through the research questionnaire instrument valid and reliable. Statistical analysis of research data using path analysis with significance in accordance with the output of spss 22.0 Findings of this study indicate that there is a positive direct effect of leadership style, the principal emphaty, motivation toward school organizational culture. There is a direct positive leadership style of emphaty and motivation principals.
\end{abstract}

Keywords: Style of Leadership, Emphaty, Motivation and Organizational Culture

\begin{abstract}
Abstrak: Tujuan dari Penelitian ini adalah untuk mengetahui pengaruh gaya kepemimpinan, empati dan motivasi terhadap budaya organisasi kepala sekolah dasar kota Gorontalo. Objek penelitian ini adalah Sekolah Dasar dengan subjek kepala sekolah sebanyak 55 orang.Empat variabel dari data penelitian di kumpul melalui instrumen berupa angket yang valid dan reliabel. Analisis statistik data penelitian menggunakan analisis jalur dengan signifikansi sesuai dengan output SPSS 22.0 Temuan penelitian menunjukkan bahwa terdapat pengaruh langsung positif gaya kepemimpinan, empati kepala sekolah, motivasi terhadap budaya organisasi sekolah.Terdapat pengaruh langsung positif gaya kepemimpinan terhadap empati dan motivasi kepala sekolah.
\end{abstract}

Kata Kunci: Gaya Kepemimpinan, Empati, Motivasi, Budaya Organisasi.

\section{PENDAHULUAN}

Peningkatan kualitas pendidikan ditujukan untuk semua jenjang pendidikan. Peningkatan kualitas secara nyata dapat dilihat melalui pengembangan fisik maupun non fisik. Pengambangan fisik dapat dilihat melalui pengambangan gedung dan perlengkapannya, sedangkan pengambangan non fisik dapat dilihat melalui kurikulum, visi dan misi sekolah serta program-program sekolah. Saat ini upaya pengembangan sekolah terlihat sangat marak sebagai dampak langsung dari peningkatan dana pendidikan sebesar 20\%. Pengembangan ini fokus dilakukan oleh seorang pemimpin dalam melaksanakan aktivitas amanah sebagai leader dalam mengelola sekolah agar dapat menciptakan budaya kerja dan pelayanan yang lebih baik dan berkualitas.

Mutu pendidikan sangat ditentukan oleh gaya, budaya, motivasi dan empati para pendidik dilembaga sekolah, terutama oleh seorang kepala sekolah dalam mengayomi para 
pendidik/guru lainnya. Kepala sekolah adalah merupakan tugas tambahan yang diembannya selain sebagai tugas pokok yang di amanahkan kepadanya adalah sebagai pendidik/guru, sehingga dari kepala sekolah tersebut dapat memberikan warna, corak, bentuk, budaya yang dapat meningkatkan kualitas pendidikan disekolahnya. Kenyataannya menunjukkan bahwa banyak kepala sekolah yang belum dapat memberikan keteladanan yang dapat menjadi panutan yang harus di gugu dan di tiru oleh bawahannya agar motivasi kerja dapat dilaksanakan dengan efektif, sehingga banyak kepala sekolah yang memiliki nilai budaya yang rendah. Kualitas pekerjaan yang tidak dapat menciptakan kondisi belajar yang kondusif karena sikap kepemimpinan yang dinilai rendah dalam memberikan pelayanan kepada bawahannya. Kualitas pekerjaan yang tidak maksimal, lambatnya informasi, faktor kehadiran yang sering terlambat dilakukan oleh pendidik sehingga membuat aiswa juga terlambat dalam kehadiran disekolah dan terlambat dalam menerima materi pelajaran, hal ini dapat mengindikasikan rendahkanya budaya kerja tugas kepala sekolah yang perlu dikaji secara spesifik.

Menurut Permen Diknas No.13 tahun 2007 tentang Standar Kompetensi Kepala sekolah terdiri dari: (1 ) Kepribadian; (2) manajer; (3) Kewirausahaan; (4) Supervisor; (5) Sosial. Berdasarkan Permen tersebut sebaiknya kepala sekolah dapat mengimplementasikan dan mengaplikasikan Permen tersebut untuk dapat meningkatkan kualitas pekerjaannya.

Banyak yang mempersoalkan tidak terciptanya budaya organisasi yang dibangun kepala sekolah di provonsi gorontalo terhadap lembaganya khususnya pada level pendidikan sekolah dasar karena dapat dilihat dari gaya kepemimpinan, empati dan motivasi yang tidak diefektif dan efisien dilaksanakan. Bahwa: pada dasarnya Gaya kepemimpinan merupakan style, sikap dan perilaku yang ditujukan oleh seseorang dalam berhubungan dengan orang lain yang dibentuk oleh pendidik dan pengalaman serta oleh pergaulan dengan lingkungan. Jelas bahwa gaya kepemimpinan dapat memengaruhi budaya organisasi, yang akan memengaruhi lingkungan, fisik seseorang, keadaan melalui pendidikan yang ditransfer melalui nilai-nilai tertentu. Juga Gaya kepemimpinan dapat memengaruhi empati, karena dengan sikap yang ditunjukkan dapat memahami orang lain. Serta gaya kepemimpinan dapat memengaruhi motivasi kerja individu dan bawahannya juga, karena dapat meningkatkan kondisi psikologis bawahannya.

Empati merupakan sikap dari seorang individu untuk memahami orang lain dari sudut pandangnya, bahwa jelas empati dapat memengaruhi budaya seorang yang memiliki tingkat empati yang tinggi sudah pasti akan selalu berusaha memahami pikiran dan emosi orang lain, yang dapat memberikan nilai. Empati bagian dari kecerdasan emosi berupa kemampuan mengenali perasaan diri kita sendiri dan perasaan orang lain, kemapuan memotivasi diri sendiri dan kemampuan mengelola emosi dengan baik pada diri sendiri dan salam hubungannya dengan orang lain. (Agus Efendi dalam Djafri. N. 2014: 43)

Motivasi menurut Geroge\&Garet adalah: sebagai proses psikologi yang mengarahkan perilaku seseorang dalam organisasi, tingkat usaha dan tingkat kegigihannya. Jelaslah motivasi dapat muncul bila bawahan merasa terdorong untuk melakukan hal yang baik karena adanya dorongan dari atasannya.

Budaya Organisasi merupakan nilai-nilai atau norma yang mengikat seseorang dalam melaksanakan tugas disuatu organisasi. Jelas bahwa budaya organisasi yang baik dapat memengaruhi motivasi, empati dan gaya kepemimpinan yang baik terhadap bawahannya, siswa dan lingkungan sekitarnya. 
Suatu organisasi dibentuk untuk mencapai tujuan tertentu. Tujuan organisasi akan dapat dicapai melalui kinerja seluruh sumberdaya manusia yang ada dalam organisasi tersebut. Faktor yang dapat merubah budaya organisasi terhadap efektifnya pekerjaan kepala sekolah yakni dengan mengubah budaya organisasi lama yang tidak baik serta tidak sesuai dengan nilai-nilai budaya organisasi baru atau yang lebih baik pada seluruh pimpinan lembaga sekolah/organisasi, bawahan:staf/pegawai/guru secara sukarela, partisipatif dan mandiri, kenyataan sekarang banyak para pemimpin dan bawahan dalam lembaga/sekolah sangat sulit untuk menjadi teladan, merubah diri sendiri, mengabaikan nilai-nilai dan budaya organisasi sekolah/lembaga tersebut.

Sekolah merupakan institusi strategis yang berupaya meningkatkan mutu pendidikan dan sumberdaya manusia. Peningkatan mutu pendidikan dan sumber daya manusia di tandai dengan peningkatan penerimaan nilai-nilai baru dan baik yang dapat merubah pola tingkah laku yang tidak baik kearah yang lebih baik, melalui pengaruh budaya organisasi, gaya kepemimpinan, empati dan motivasi. Untuk melaksanakan budaya organisasi secara baik akan menimbulkan empati yang tinggi dan motivasi kerja. Secara bersamaan bahwa gaya kepemimpinan, empati, motivasi kerja yang tinggi akan dapat meningkatkan budaya kerja kepala sekolah dalam organisasi.

Bertitik tolak dari latar belakang masalah tersebut peneliti memandang perlu melakukan penelitian untuk mengungkap pengaruh variabel gaya kepemimpinan, empati dan motivasi terhadap budaya organisasi kepala sekolah dasar se Kota Gorontalo, dengan judul Pengaruh Gaya Kepemimpinan, Empati dan Motivasi terhadap Budaya Organisasi Kepala Sekolah Dasar Se Kota Gorontalo.

Tujuan Penelitian ini adalah untuk mengidentifikasi pengaruah antara variabelvariabel yang terlibat dalam penelitian. Variabel penelitian dibagi menjadi dua yaitu: variabel terikat (dependent variable) dan variabel bebas (independent variable). Variabelvariabel tersebut adalah gaya kepemimpinan $\left(\mathrm{X}_{1}\right)$, empati $\left(\mathrm{X}_{2}\right)$, Motivasi $\left(\mathrm{X}_{3}\right)$ sebagai variabel bebas, sedangkan variabel terikat adalah budaya organisasi (Y).

\section{KAJIAN TEORI}

Budaya Organisasi. Budaya Organisasi adalah faktor penting dalam mewujudkan suatu keadaan, nilai, aturan yang sering dikaji oleh para ilmuwan berdasarkan latar belakang pendidikan, lembaga/organisasi yang ditekuninya.Hal ini menunjukkan bahwa budaya organisasi dapat memberikan manfaat dan kontribusi langsung maupun tidak langsung terhadap perkembangan organisasi. Robbin, (2009: 305) menyebutkan budaya organisasi adalah sejumlah pemahaman penting seprti norma, nilai, dan keyakinan yang dimiliki bersama oleh anggota organisasi.

Menurut Ivancevich, Konopaske \& Matteson (2008: 36-37) menyebutkan budaya organisasi merupakan suatu perspektif untuk memahami sikap individu dan kelompok di dalam organisasi yang memiliki batasan-batasan dan budaya organisasi adalah apa yang pegawai rasakan dan bagaimana persepsi ini menciptakan suatu bentuk aturan-aturan, nilai-nilai dan harapan.

Sesuai pendapat Jenifer M. George \& Greath R. Jones (2006: 535) Budaya organisasi adalah sekumpulan nilai, aturan dan norma yang mempengaruhi cara pegawai berpikir, merasakan dan berprilaku satu sama lainnya dan terhadap orang lain, di dalam dan diluar efektivitas organisasi. 
Budaya organisasi pada dasarnya akan mewakili norma-norma perilaku yang diikuti oleh para anggota organisasi, termasuk mereka yang berada dalam hirarki organisasi. Organisasi yang masih di dominasi oleh pendiri misalnya, maka budaya akan menjadi wadah untuk mem fasilitasi harapan-harapan pendiri pada pekerja lainnya. Demikian halnya jika organisasi dikelola oleh seorang manajer senior yang bersifat otokratis yang menerapkan gaya kepemimpinan yang otokratis yang menerapkan gaya kepemimpinan "top down" maka budaya juga akan berperan mengkomunikasikan harapan-harapan mereka.

Mc Shane\& Von Glinow (2007: 458) budaya organisasi terdiri dari nilai-nilai dan asumsi-asumsi yang digunakan bersama di dalam sebuah organisasi. Budaya organisasi menjelaskan apa yang penting di dalam perusahaan dan berakibat langsung terhadap setiap orang dalam organisasi kearah yang benar dalam bekerja.

Menurut Robins ada tujuh ciri budaya organisasi yaitu: (1) inovasi dan pengambilan resiko. Sejauh ini karyawan didukung untuk menjadi inovatif dan mengambil resiko (2) Perhatian terhadap detail. Sejauhmana karyawan diharapkan menunjukkan kecermatan, analisis dan perhatian terhadap detail (3) orientasi hasil (4) orientasi orang (5) orientasi tim (6) Keagresipan (7) kemantapan. Organisasi menekankan dipertahankan budaya organisasi yang sudah baik.

Berdasarkan uraian diatas, dapat disimpulkan bahwa budaya adalah penerapan nilainilai, norma-norma bersama dalam lembaga/organisasi yang dilakukan oleh seseorang yang tercermin dalam nilai-nilai yang menjadi karakter pribadi, terbentuk dari suatu proses interaksi dengan orang lain dalam lembaga/kelompok yang mempengaruhi tindakan seluruh anggota organisasi dalam memudahkan pencapaian tujuan organisasi secara efektif, dengan indikator berupa: (1) adanya kebersamaan dalam sekolah/organisasi, (2) kepercayaan terhadap transfer nilai, (3) disiplin dalam melaksanakan, (4) ada sangsi untuk yang melanggar aturan, nilai, norma. (5) semangat kerja sebagai wujud berbudaya

Gaya Kepemimpinan. Gaya kepemimpinan menurut Mulyasa adalah cara yang dipergunakan pemimpin dalam memengaruhi para pengikutnya (2002: 108). Menurut Thoha gaya kepemimpinan merupakan norma perilaku yang digunakan seseorang pada saat orang tersebut mencoba memengaruhi perilaku orang lain seperti yang ia lihat (Miftah Thoha, 2001:52). Sejalan dengan pendapatnya Lussier (2009) memberi arti kepemimpinan adalah proses memengaruhi karyawan/bawahan. Agar bekerja ke arah pencapaian tujuan organisasi. Dalam hal ini usaha menselaraskan persepsi di antara orang yang akan mempengaruhi perilaku dengan bentuk yang akan dipengaruhi menjadi amat penting kedudukannya. Gaya kepemimpinan merupakan suatu pola perilaku seorang yang khas pada saat memengaruhi anak buahnya, apa yang dipilih oleh pemimpin untuk dikerjakan, cara pemimpin bertindak dalam memengaruhi anggota kelompok membentuk gaya kepemimpinannya.

Gaya kepemimpinan menurut Morgan James dibagi atas gaya authoritarian dan partisipative (Morgan E. James, 2009: 126). Selanjutnya Mc. Grogor dan M. Douglas mengatakan bahwa gaya authotitarian disebut sebagai theori $\mathrm{X}$ dan partisipative sebagai teori Y. Menurut Herabudin membagi gaya Kepemimpinan Kepala sekolah menjadi 4, yaitu: (1) gaya autoritarian, (2) gaya laissez-faire, (3) gaya demokratis, (4) gaya pseudo demokratis (Soetopo Hendiyat dan Soemanto Westy, 1988: 7). 
HouseRobert J., dan Terence R. Mitchel, 2003:81-97 mengemukakan empat jenis kepemimpinan, yaitu; (1) kepemimpinan direktif, (2) kepemimpinan yang mendukung, (3) kepemimpinan partisipatif, dan (4) kepemimpinan yang berorientasi pada prestasi.

Lebih lanjut Tannembaum dalam Thoha mengemukakan model gaya pembuatan keputusan yang dilakukan kepala sekolah. Ketujuh model ini masih dalam kerangka dua gaya otokratis dan demokratis di atas. Ketujuh model keputusan pemimpin itu antara lain: (1) pemimpin membuat keputusan dan kemudian mengumumkan kepada bawahannya, (2) pemimpin menjual keputusan, (3) pemimpin memberikan pemikiran-pemikiran atau ideide dan mengundang pertanyaan-pertanyaan, (4) pemimpin memberikan keputusan bersifat sementara yang kemungkinan dapat diubah, (5) pemimpin memberikan persoalan, meminta saran-saran, dan membuat keputusan, (6) pemimpin merumuskan batas-batasnya, dan meminta kelompok bawahan untuk membuat keputusan, dan (7) pemimpin mengizinkan bawahan melakukan fungsi-fungsinya dalam batas-batas yang telah dirumuskan oleh pimpinan (Robert Tannenbaum dan Warren H. Schmidt, 1958, p. 96 dalam Thoha 2003: 262).

Berdasarkan pembahasan di atas, maka yang dimaksud dengan gaya kepemimpinan kepala sekolah adalah perilaku kepala sekolah dalam memimpin, mengarahkan, membina dan mempengaruhi bawahan dalam kegiatan pembelajaran di sekolah. Berdasarkan hal tersebut maka dimensi gaya kepemimpinan kepala sekolah dalam penelitian ini adalah bersifat terbuka, mendominasi pelaksanaan tugas, dan situasional.

Empati. Manusia adalah makhluk sosial sehingga tidak dapat dilepaskan dari pengaruh lingkungan sosialnya.Namun begitu reaksi individu terhadap lingkungan berbedabeda.Ada sebagian memberikan reaksi positif terhadap lingkungannya, adapula sebagian memberikan reaksi biasa saja terhadap lingkungannya. Menurut Honey dalam Baron dan Byme (2005: 350) terdapat tiga jenis interaksi social manusia, yaitu: (1) individu yang termotivasi menolong individu lainnya; (2) individu yang menolak menolong individu lainnya, dan (3) individu yang suka menentang individu lainnya. Dari ketiga jenis diatas yang lebih dapat bereaksi positif terhadap lingkungannya adalah yang pertama karena memiliki perilaku social.

Salah satu bentuk perilaku social adalah empati, yang berarti berusaha memahami orang lain sesuai dengan sudut pandang orang tersebut (Morgan, 2009: 447). Menurut Franzoi (2003: 500) mendefinisikan empati sebagai, "A feeling compassion and tenderness upon viewing a victim's plight”. Berbeda dengan pendapat di atas, empati dapat juga diartikan sebagai: kemampuan untuk mengalami pikiran dan emosi orang lain.

Perliku sosial tidak akan muncul serta merta namun melalui sebuah proses keputusan yang panjang. Perumusan perilaku diawali dengan: (1) adanya perhatian terhadap sebuah situasi, (2) menginterpretasikan dengan benar (3) dihubungkan dengan tanggungjawab sebagai salah satu makhluk social (4) mengambil keputusan untuk menolong (5) memilih tindakan yang sesuai dengan kemampuannya, maka perilaku pro social pada dasarnya lahir karena adanya perhatian dan kepedulian terhadap sesuatu atau seseorang dalam situasi yang bagaimanapun.

Empati menurut Batson dalam Franzoi (2006:500) muncul karena ingin membantu orang lain dari penderitaan yang dialaminya (type ini disebut altruistic). Adapula yang membantu karena ingin disebut pahlawan (type ini disebut egoistic sebab bersikap karena oleh keadaan kebutuhan egoistisnya). 
Berdasarkan hasil penelitian oleh Davis yang dikutip oleh Franzoi (2003:503) menyatakan bahwa, individu yang memiliki tingkat empati yang tinggi cenderung merasa terpanggil untuk membantu orang lain keluar dari penderitaannya. Sedangkan menurut Hatmodjosoewito (2010:109), empati adalah kemampuan perseorangan untuk menempatkan dirinya pada situasi orang lain atau upaya memahami perasaan orang lain yang tidak mempunyai arti emosional bagi dirinya, karena adanya interaksi dua orang atau lebih

Jika dikaitkan dengan tugas kepala sekolah dasar di kota gorontalo dalam menjalankan tugas, maka kepala sekolah memiliki empati yang tinggi, selalu berusaha untuk memahami pikiran dan perasaan para gurunya, ketika mereka mengalami kesulitan dalam kegiatan pendidikan maka kepala sekolah berusaha melepaskannya dari kesulitan yang mereka alami sesuai dengan tingkatan kesulitan yang dialaminya. Tindakan ini berupa usaha kepala sekolah dalam memberikan empati dengan caramencari cara penyelesaian dengan membebaskan dan memahami gurunya dalam mengalami kesulitan melalui perspektifnya dan gurunya tersebut.Berdasarkan uraian diatas yang dimaksud dengan empati dapat didefinisikan: sebagai kepedulian dan tindakan yang dilakukan kepala sekolah terhadap kesulitan yang dialami para guru dan karyawan dalam hal: (1) kemampuan bekerja (2) hubungan social (3) masalah keuangan.

Motivasi. Motivasi merupakan suatu proses yang terjadi dalam diri seseorang atau proses psikologis. Motivasi (motivations) berasal dari bahasa latin "movere" yang artinya bergerak, sehingga motivasi sering didefinisikan sebagai proses yang dimulai dengan kurangnya sesuatu yang bersifat phsycologi atau psikologi atau kebutuhan yang menggerakkan perilaku atau dorongan untuk memenuhi kebutuhan itu. Secara umum katakata seperti hasrat, keinginan, harapan, dorongan, tujuan, kebutuhan, motif dan insentif dilibatkan dalam definisi motivasi.

Motivasi menurut dalam pemikiran merupakan proses psikologi, terjadi interaksi antara sikap, kebutuhan, persepsi, proses belajar dan pemecahan masalah. Hal ini antara lain menyebabkan George dan Jones merumuskan motivasi dipusatkan untuk mengaktifkan perilaku, mengarahkan dan menghentikannya atau motivasi sebagai proses psikologi yang mengarahkan perilaku seseorang dalam organisasi, tingkat usaha dan tingkat kegigihannya.( Danim, 2004).

Hal tersebut senada dengan Robbins and Judge, mengatakan motivasi kerja adalah; Proses yang menggambarkan intensitas, arah, dan ketekunan usaha individu dalam mencapai tujuan.Intensitas berkenaan dengan bagaimana seseorang berusaha keras. Petunjuk atau arah berkenaan dengan kualitas usaha dan konsistensi, sedangkan kegigihan berkenaan dengan ukuran seberapa lama dapat menjaga usahanya.

Sementara menurut Ivancevich, John M. Human Resources, (2001: 56), motivasi adalah; serangkaian sikap yang memengaruhi seseorang untuk bertindak mencapai tujuan atau suatu dorongan dari dalam yang memberikan tenaga, menyalurkan, dan memelihara perilaku manusia dalam mencapai tujuan.

Menurut Wagner dan Hollenbeck; The energy a person is willing to deveto to a task. Motivasi sebagai energy seseorang berupa kemauan yang kuat untuk menyelesaikan tugas.

Mulins (2005), mengidentifikasi empat ciri umum motivasi yang mendasari definisi motivasi yakni; (1) motivasi dicirikan sebagai fenomena individu, (2) motivasi selalu digambarkan sebagai kesenjangan, (3) motivasi terdiri dari banyak aspek, (4) tujuan teorimotivasi adalah untuk meramalkan perilaku. Berdasarkan hal diatas dapat dirumuskan 
bahwa motivasi didasarkan terhadap tingkat individu dan memilih untuk mengerjakan sesuatu dengan perilaku tertentu yang spesifik.Perilaku seseorang ditentukan oleh motivasinya.

Sementara Kreitner, Robert and Kinicki, 2007: 236, mendefinisikan bahwa motivasi merupakan, psychological processes that arouse and direct goal directed behavior. Sikap yang mempengaruhi seseorang untuk bertindak dengan tujuan tertentu dan cara yang terarah. Hal ini merupakan kondisi internal yang menuntun seseorang untuk berprilaku atau berbuat sesuatu.Gibson, 2009: 130. berpendapat bahwa motivasi adalah kekuatan yang mendorong seseorang/individu yang menimbulkan dan mengarahkan perilaku.

Casio,Wayne F Casio, dalam Ayudia (2008:15), menyebutkan motivasi kerja adalah kekuatan yang dari individu untuk memuaskan kebutuhan maka kebutuhan yang terpusat tidak akan lagi merupakan motivasi kerja. Istilah yang lain untuk motivasi adalah kebutuhan (need), keinginan (wont) atau dorongan (drives). Dengan dorongan inilah orang berprilaku, yaitu mengendalikan dan memelihara kegiatan-kegiatan, menerapkan arah untuk mencapai tujuan.Dalam psikologis tujuan ini disebut insentif. Motivasi adalah proses dimulai dari kekurangan kebutuhan yang mengaktifkan perilaku atau dorongan yang diperlukan pada pencapaian proses tujuan atau insentif.

Teori motivasi lainnya seperti dikemukakan oleh Colcuitt, Jason, LePine, Jeffery A dan Wesson, (2009:186), adalah goal setting theory dan equity theory.Teori yang melihat tujuan sebgaai penggerak utama dari intensitas usaha. "Pengetahuan bahwa motivasi bukan hanya tergantung pada keyakinan sendiri dan lingkungan atau lingkarannya tapi juga pada apa yang terjadi dengan orang lain.

Dapat dijabarkan bahwa; Motivasi kerja terdiri dari, faktor intrinsik dan ekstrinsik yaitu berupa: tujuan, kebutuhan, kepribadian, emosi, motif atau keinginan dan harapan. Sedangkan faktor ekstrinsik terdiri dari ganjaran dan hukuman.

Ada dua jenis teori motivasi yang secara umum banyak dikaji dan ditelaah terutama dalam perilaku organisasi yang digunakan sebagai ukuran kerja individu. Pertama teori isi, yang berfokus kepada "apa", mengidentifikasi faktor-faktor yang menyebabkan individu melakukan usaha dalam kerja. Dengan demikian pendekatan ini berusaha mengidentifikasi kebutuhan seseorang yang relatif kuat dan tujuan yang dikejar untuk memenuhi kebutuhan tersebut. Kedua, teori proses yang berfokus kepada "bagaimana" langkah-langkah individu menempatkan usaha. Dengan demikian pendekatan ini berupaya mengidentifikasi hubungan antara faktor-faktor yang membentuk motivasi. Pendekatan ini juga menjelaskan bagaimana motivasi diaktifkan, sehingga cenderung dapat menjelaskan pilihan, keteguhan usaha yang berarti, fokusnya pada bagaimana perilaku dimulai, diarahkan dan dipelihara atau dipertahankan.

Motivasi kerja sebenarnya dapat dibedakan dalam tiga kelompok besar yakni yang berlandaskan pada kebutuhan, kesadaran dan pemberian dukungan atau yang sering disebut penguatan (reinforcement).

Dari penjelasan diatas, definisi motivasi kerja dalam penelitian disintesiskan adalah dorongan atau semangat psikologis seseorang yang menentukan arah perilaku individu, organisasi atau masyarakat dalam tingkat upaya atau tingkat ketekunan, dengan indikator: (1) kesesuaian perilaku dengan mekanisme dan aturan-aturan, (2) kesesuaian aktivitas kerja dengan mekanisme dan aturan-aturan, (3) upaya dalam mengatasi hambatan. (4) melakuan aktivitas sesuai prosedur, (5) pencapaian keunggulan tujuan bersama-sama. 


\section{Kerangka Teoritik}

1. Pengaruh Gaya Kepemimpinan terhadap Budaya Organisasi. Kepala sekolah merupakan pemimpin tertinggi di sekolah. Dalam melaksanakan tugasnya kepala sekolah di pengaruhi oleh gaya kepemimpinannya yang dapat memberikan kontribusi nilai positif untuk menciptakan budaya organisasi agar lebih baik. Gaya kepemimpinan yang dilakukan oleh kepala sekolah dalam memimpin bawahannya harus dapat mengelola kegiatan sekolah secara efisien dan efektif sesuai dengan tujuan yang diharapkan bersama.Gaya kepemimpinan kepala sekolah harus dapat menjalankan amanah secara transparan, dapat berorientasi pada nilai azaz kemanfaatan berdasarkan situasi dan kondisi yang diwujudkan oleh seluruh unsur sekolah, dengan hasil situasi dan kondisi demikian dapat menjadi suatu budaya sekolah. Hal ini senada dengan pernyataaan Brahmasari.I.A. dan Suprayetno. A. dalam penelitiannya bahwa dalam menciptakan budaya organisasi yang harmonis dapat di ciptakan oleh seorang pemimpin yang memiliki gaya kepemimpinan yang mampu memotivasi bawahan melakukan perubahan kearah organisasi yang lebih baik serta dapat menciptakan suasana yang harmonis dilingkungan organisasi/lembaga/perusahaan.

Dengan demikian kepala sekolah dengan gaya kepemimpinan yang dapat mewadahi bawahannya melalui sikap bersifat terbuka, mendominasi pelaksanaan tugas, dan situasional akan direspon positif oleh seluruh unsur sekolah, yang pada akhirnya akan dapat mempengaruhi budaya organisasi. Berdasarkan pemikiran inilah dapat diduga bahwa terdapat pengaruh positif gaya kepemimpinan kepala sekolah terhadap budaya organiasasi sekolah.

2. Pengaruh Empati terhadap Budaya Organisasi. Empati merupakan sikap bagian kecerdasan emosi yang harus dimiliki oleh seorang individu. Khususnya kepala sekolah baiknya ada rasa sikap empati, tentulah untuk dapat memahami orang lain dari sudut pandangnya dengan pemahaman yang dapat dirasakan oleh orang yang membutuhkannya. Empati adalah sikap yang harus dibutuhkan oleh seorang kepala sekolah agar dapat memanfaatkan potensi-potensi yang dimiliki bawahannya. Kepala sekolah tidak akan dapat bekerja sendiri secara ptimal jika tidak dapat mengkomunikasikan atau membantu para guru dalam menyelesaikan masalah mereka guna memperoleh hasil kerja yang maksimal, yakni dapat menghasilkan keluaran atau lulusan yang terbaik.

Setelah kepala sekolah dapat mencarikan solusi dari para guru untuk dapat memposisikan dirinya sama dengan bawahannya maka ini akan menjadi suatu iklim komunikassi yang efektif, jika hal ini sudah ada dalam diri setiap pemimpin dan menjadi suatu keputusan yang biasa dilakukan oleh kepala sekolah dalam menyelesaikan masalah maka ini merupakan suatu nilai budaya yang dapat dirasakan manfaatnya oleh semua unsur sekolah dalam menyelesaikan setiap hambatan dan kesulitan disekolah. Hal ini di dukung oleh hasil penelitian Utami (2014: 32) dalam Jurnal Ilmiahnya bahwa empati bagian dari emosi yang dikendalikan melalui kecerdasan seorang pemimpin yang mampu memotivasi, menyelesaikan masalah bawahannya untuk mencapai target pekerjaannya sesuai dengan yang diharapkan, serta pemimpin harus memiliki tingkat kepedulian terhadap bawahannya sehingga ada pengaruh bawahan dengan atasan melalui empati yang diciptakan oleh pimpinan terhadap atasan dan atar sesama bawahan, hal inilah yang menjadi budaya baik dalam organiasi, sehingga terdapat pengaruh variabel empati dan budaya Organisasi melalui pengaruh hubungan kerja Empati, Budaya Organisasi dan Gaya Kepemimpinan. 
Berdasarkan pemikiran inilah maka dapat diduga terdapat pengaruh positif empati terhadap budaya organisasi.

3. Pengaruh Motivasi terhadap Budaya Organisasi. Motivasi yang dibangun oleh kepala sekolah dalam lingkungan pendidikan akan dapat menghasilkan suatu hasil. Motivasi dapat muncul karena ada dorongan kebutuhan manusaia. Untuk memenuhi kebutuhan seseorang dapat melakukan sesuatu melalui kerja sikap dan perilaku yang dapat memberikan nilai sebagai keteraturan dalam efektivitas hasil kerja.

Seseorang yang termotivasi untuk melakukan pekerjaan dan pekerjaan itu bila di kerjakan sesuai dengan aturan yang memperhatikan norma, wewenang dan tujuan yang jelas maka akan menjadi suatu kebiasaan atau aturanyang dapat diikuti oleh seluruh elemen organisasi. Menurut penelitian Nugraha, Astusi dan Hakam (2013)bahwa bawahan memiliki semangat kerja yang tinggi sangat di pengaruhi oleh Motivasi dari seorang pemimpin yang memiliki gaya kepemimpinan otokratis sangat mengerti, menciptakan efektivitas komunikasi akan lingkungan yang beretika sehingga tercipta budaya organisasi melalui motivasi kepemimpinan yang baik. Sesuai dengan pemikiran tersebut diatas maka di duga terdapat pengaruh positif motivasi terhadap budaya organisasi.

4. Pengaruh Gaya Kepemimpinan terhadap Empati. Gaya kepemimpinan oleh kepala sekolah secara teknis akademis dapat disesuaikan dengan situasi dan kondisi kebutuhan para bawahan, berdasarkan kesepahaman sikap, perlaku, pikiran antara kepala sekolah dan bawahannya atas segala inisiatif dan kreativitas yang mengarah pada rasa empati dari atasan kepada bawahan atas perkembangan dan keamajuan seluruh elemen sekolah. Berdasarkan pemikiran inilah maka diduga terdapat pengaruh positif gaya kepemimpinan terhadap empati.

5. Pengaruh Gaya Kepemimpinan terhadap Motivasi. Gaya kepemimpinan oleh kepala sekolah dapat memengaruhi motivasi, sebab motivasi dapat muncul jika ada dorongan kebutuhan manusia dalam melakukan sesuatu. Tuntutan kebutuhan termasuk pekerjaan yang semakin tinggi akan dapat mendorong seseorang melakukan suatu aktivitas. Gaya kepemimpinan yang dilakukan oleh seorang kepala sekolah misalnya gaya demokratis untuk melaksankan pekerjaan sesuai dengan instruksinya kepada bawahannya, jika pekerjaan dilaksanakan dengan tujuan dan hasil prestasi yang lebih baik maka pekerjaan tersebut telah memenuhi kebutuhan yang diharapkan oleh seluruh elemen sekolah. Hal ini sesuai dengan pendapat Newstrom (2007) kebutuhan akan potensi ( $n$ Ach) merupakan daya penggerak yang memotivasi semangat bekerja seseorang.RivaiVethzal (2003:2) mendefinisikan kepemimpinan adalah proses memengaruhi dalam menentukan tujuan organisasi, memotivasi perilaku pengikut untuk mencapai tujuan, memengaruhi, memotivasi untuk memperbaiki kelompok dan budayanya. Yukl (2009:4) mendefinisikan kepemimpinan adalah kemampuan individu untuk memengaruhi, memotivasi dan membuat orang lain mampu memberikan kontribusinya demi efektivitas dan keberhasilan organisasi. Andrian Gostick dan Chester Elton (2009) dalam bukunya The Carrot Principle menyatakan ada empat hal yang mendasari kepemimpinan yang efektif, yaitu penentuan tujuan( o o al setting), komunikasi (communication), kepercayaa $\mathrm{n}$ (trust), dan tangung jawab (Accountability). Peningkatan keefektifan kepemimpinan kepala sekolah dapat di kembangkan melalui pelaksanaan peran kepala sekolah sebagai pendidik, manajer, administrator, dan supervisor. 
Sejalan dengan pemikiran tersebut diatas maka di duga terdapat pengaruh positif Gaya Kepemimpinan terhadap motivasi.

\section{Kerangka Konseptual}

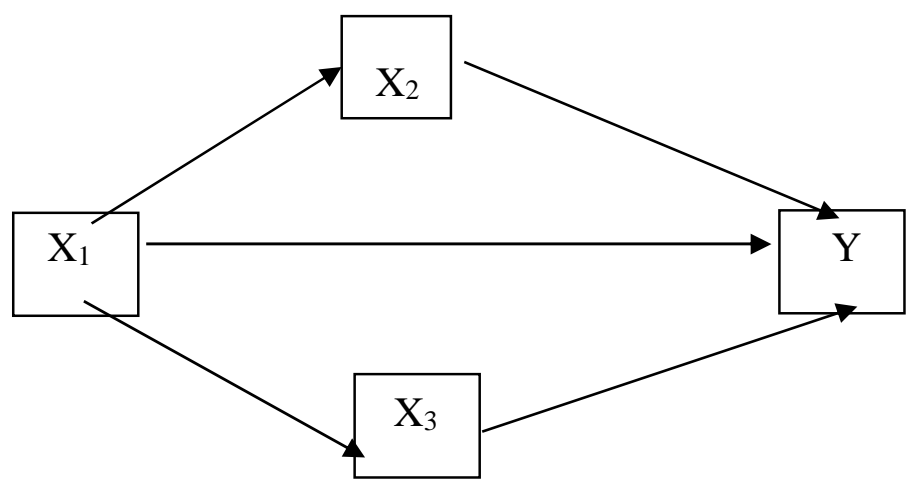

Gambar 1. Kerangka Konseptual

Untuk kepentingan penelitian hubungan antara Variabel Terikat dan variabel Bebas, disimpulkan $X_{1}$ : (Gaya Kepemimpinan Kepala Sekolah), $X_{2}$ : (Empati), $X_{3}$ : (Motivasi), Y: (Budaya Organisasi)Sebagai variabel terikat.

\section{Hipotesis}

1. Terdapat pengaruh gaya kepemimpinan terhadap budaya organisasi

2. Terdapat pengaruh empati terhadap budaya organisasi

3. Terdapat pengaruh motivasi terhadap budaya organisasi.

4. Terdapat pengaruh gaya kepemimpinan terhadap empati

5. Terdapat pengaruh gaya kepemimpinan terhadap motivasi

\section{METODE}

Metode yang digunakan dalam penelitian ini adalah survey kausal dengan model analisis jalur (Path Analysis) dalam penelitian ini terdapat empat variabel, yaitu: gaya kepemimpinan $\left(\mathrm{X}_{1}\right)$, empati $\left(\mathrm{X}_{2}\right)$, motivasi $\left(\mathrm{X}_{3}\right)$ dan Budaya organisasi $(\mathrm{Y})$. Populasi dan Sampel. Populasi adalah seluruh kepala sekolah dasar dikota gorontalo dengan sampel yang diambil secara random sebanyak 55 kepala sekolah.

Metode Analisis Data. Analisis data penelitian ini menggunakan analisis deskriptif dan inferensial.Analisis deskriptif dimaksudkan untuk memberikan gambaran karakteristik penyebaran skor data hasil penelitian.Sedangkan analisis statistik inferensial digunakan untuk menguji hipotesis dengan teknik analisis jalur yang di dahului dengan pengujian prasyarat analisis yang meliputi uji linieritas persamaan regresi dan uji normalitas data. (Sugiyono).

\section{HASIL DAN PEMBAHASAN}

Deskripsi Umum Responden. Demografi Responden. Teknik penarikan sampel pada penelitian ini menggunakan simple random. Kuisioner yang disebarkan sebanyak 55 
eksemplar.Pada 55 responden. Untuk meningkatkan response rate, penelitian ini menggunakan metode penyampaian langsung dalam menyebarkan kuesioner sehingga.

Pengujian Kualitas Data.Uji validitas data, Pengujian validitas data dalam penelitian ini adalah dengan menggunakan korelasi produk momen sedangkan reliabilitas instrumen menggunakan Alpha Crombach. Hasil analisis menunjukkan bahwa variabel gaya kepemimpinan diperoleh 28 butir soal valid dengan reliabilitas 0.940. Variabel empati kepala sekolah 30 butir valid dengan reliabilitas 0.970. Variabel Motivasi 29 butir valid dengan realiabilitas 0.967 dan variabel budaya organisasi dengan 30 butir soal dengan reliabilitas 0.925

Analaisis Data. Pengujian Persyaratan Analisis. Persyaratan yang perlu dipenuhi yaitu data memiliki distribusi normal dan hubungan antara variabel linier dan aditif. Sehingga dilakukan pengujian persyaratan analisis berupa: Uji Linieritas Regresi dan Uji Normalitas Galat Taksiran.

1. Uji Linieritas Regresi. Uji linieritas dimaksudkan untuk melihat apakah hubungan $Y$ dengan $X_{i}$ yang ditujukan oleh persamaan regresi sederhana $\hat{Y}=a+b X_{i}, i=1,2,3$, bersifat linier atau non linier. Analisis dengan bantuan SPSS 22,0 dengan kriteria pengujian untuk siginfikansi menggunakan kriteria apad output SPSS.

Tabel 1. Rangkuman pengujian linieritas persamaan regresi

\begin{tabular}{cccl}
\hline Pers. Regresi & $\mathrm{F}_{\text {hitung }}$ & Sig & Ket \\
\hline$\hat{Y}=34.999+0.829 \mathrm{X}_{1}$ & 98,672 & 0,00 & Linier \\
$\hat{\mathrm{Y}}=49.952+0.654 \mathrm{X}_{2}$ & 36,00 & 0,00 & Linier \\
$\hat{\mathrm{Y}}=43.513+0.750 \mathrm{X}_{3}$ & 71,846 & 0,00 & Linier \\
$\mathrm{X}_{2}=50,997+0.602 \mathrm{X}_{1}$ & 11.828 & 0,00 & Linier \\
$\mathrm{X}_{3}=13,079+0.886 \mathrm{X}_{1}$ & 139,905 & 0,00 & Linier \\
\hline
\end{tabular}

Berdasarkan data di atas maka dapat disimpulkan bahwa seluruh persamaan regresi bersifat linier.

2. Uji Normalitas Galat Taksiran. Pengujian normalitas data penelitian bertujuan untuk menguji apakah data hasil penelitian berdistribusi normal atau tidak.Uji statistik yang digunakan pada penelitian ini adalah uji Kolmogorov-Smirnov ${ }^{\mathrm{a}}$ pada SPSS 22,0.

Tabel 2. Rangkuman pengujian normalitas galat taksiran

Tests of Normality

\begin{tabular}{lcrrrrr}
\hline & \multicolumn{3}{c}{ Kolmogorov-Smirnov $^{\mathrm{a}}$} & \multicolumn{3}{c}{ Shapiro-Wilk } \\
\cline { 2 - 8 } & Statistic & df & \multicolumn{1}{c}{ Sig. } & Statistic & df & \multicolumn{1}{c}{ Sig. } \\
\hline Budaya Organisasi & .094 & 55 & $.200^{*}$ & .976 & 55 & .336 \\
Motivasi & .109 & 55 & .151 & .934 & 55 & .005 \\
Empati Kepala & .073 & 55 & $.200^{*}$ & .976 & 55 & .328 \\
Sekolah & .061 & 55 & $.200^{*}$ & .983 & 55 & .648 \\
Gaya Kepemimpinan & & &
\end{tabular}

*. This is a lower bound of the true significance.

a. Lilliefors Significance Correction 
Berdasarkan hasil uji normalitas di atas maka dapat disimpulkan bahwa keseluruhan data berdistribusi normal.

Pengujian Hipotesis. HASIL ANALISIS pengujian hipotesis dilakukan dengan menggunakan SPSS 22,0. Rangkuman hasil pengujian hipotesis di atas dapat dilihat pada Tabel 3.

Tabel 3. Rangkuman Hasil perhitungan dan pengujian koefisian jalur

\begin{tabular}{ccccc}
\hline \multicolumn{2}{c}{ Koefisien jalur } & $\mathrm{t}_{\text {hitung }}$ & sig & Keberartian \\
\hline $\mathrm{p}_{\mathrm{y} 1}$ & 0.392 & 2,447 & 0.018 & Signifikan \\
$\mathrm{p}_{\mathrm{y} 2}$ & 0.258 & 2.715 & 0.009 & Signifikan \\
$\mathrm{p}_{\mathrm{y} 3}$ & 0.305 & 2.108 & 0.040 & Signifikan \\
$\mathrm{P}_{21}$ & 0.603 & 5.498 & 0.000 & Signifikan \\
$\mathrm{P}_{31}$ & 0.852 & 11.828 & 0.000 & Signifikan \\
\hline
\end{tabular}

Tabel 3 menunjukan bahwa koefisian jalur antara gaya kepemimpinan dengan budaya organisasi $\left(\mathrm{p}_{\mathrm{y} 1}\right)$ diketahui nilai $\mathrm{t}_{\mathrm{itung}}=2.447$, dengan nilai signifikansi $=0.018$ maka dapat disimpulkan bahwa koefisien jalur tersebut signifikan sehingga dapat disimpulkan bahawa hipotesis yang menyatakan bahwa terdapat pengaruh langsung positif gaya kepemimpinan terhadap budaya organisasi diterima.

Sementara untuk koefisian jalur empati kepala sekolah dengan budaya organisasi $\left(\mathrm{p}_{\mathrm{y} 2}\right)$ diketahui nilai $\mathrm{t}_{\text {hitung }}=2,715$, dengan nilai signifikansi $=0.009$ maka dapat disimpulkan bahwa koefisien jalur tersebut signifikan. maka dapat disimpulkan bahwa koefisien jalur tersebut signifikan sehingga dapat disimpulkan bahawa hipotesis yang menyatakan bahwa terdapat pengaruh langsung positif empati kepala sekolah terhadap budaya organisasi diterima

Koefisien jalur motivasi dengan budaya organisasi $\left(\mathrm{p}_{\mathrm{y} 3}\right)$ diketahui nilai $\mathrm{t}_{\text {hitung }}=2.108$ dengan nilai signifikansi $=0.040$ maka dapat disimpulkan bahwa koefisien jalur tersebut signifikan. sehingga dapat disimpulkan bahawa hipotesis yang menyatakan bahwa terdapat pengaruh langsung positif motivasi terhadap budaya organisasi diterima

Berdasarkan tabel di atas diperoleh bahwa koefisian jalur antara gaya kepemimpinan dengan empati $\left(\mathrm{p}_{21}\right)$ diketahui nilai $\mathrm{t}_{\text {hitung }}=5.498$ dengan nilai signifikansi $=0.000$ maka dapat disimpulkan bahwa koefisien jalur tersebut signifikan. sehingga dapat disimpulkan bahawa hipotesis yang menyatakan bahwa terdapat pengaruh langsung positif gaya kepemimpinan terhadap empati kepala sekolah diterima

Untuk koefisian jalur gaya kepemimpinan dengan motivasi ( $\left.\mathrm{p}_{31}\right)$ diketahui nilai $\mathrm{t}_{\text {hitung }}$ $=11.828$ dengan nilai signifikansi $=0.000$ maka dapat disimpulkan bahwa koefisien jalur tersebut signifikan. sehingga dapat disimpulkan bahawa hipotesis yang menyatakan bahwa terdapat pengaruh langsung positif gaya kepemimpinan terhadap motivasi diterima

Berdasarkan hasil analisis data yang telah diuraikan sebelumnya, maka temuan penelitian ini dapat dijelaskan bahwa terdapat pengaruh langsung positif gaya kepemimpinan terhadap budaya organisasi, berdasarkan nilai koefisien jalurnya yang signifikan yakni $p_{y 1}=0,392$. Demikian juga pengaruh langsung positif gaya kepemimpinan terhadap empati dengan nilai koefisien jalurnya yang signifikan yakni $\mathrm{p}_{21}=0,603$. Pengaruh langsung positif gaya kepemimpinan terhadap peningkatan motivasi organisasi ditunjukkan oleh nilai koefisien jalurnya yang sinifikan yakni $\mathrm{p}_{31}=0,852$ hal ini menunjukkan bahwa gaya kepemimpinan dapat memberikan konstribusi sikap dan 
perilaku terhadap peningkatan nilai budaya organisasi, empati dan motivasi organisasi. Ketiga hasil pengujian hipotesis menunjukkan bahwa gaya kepemimpinan memiliki pengaruh langsung positif terhadap peningkatan budaya organisasi, dan secara tidak langsung melalui variabel empati dan motivasi berprestasi.

Gaya kepemimpinan dapat memengaruhi oranglain melalui keadaan sekitar, sesuai dengan pendapat Thoha: 2002 gaya kepemimpinan merupakan norma perilaku yang digunakan seseorang pada saat orang tersebut mencoba memengaruhi perilaku orang lain seperti yang ia lihat, dengan demikian gaya kepemimpinan dapat memengaruhi budaya organisasi guru karena dengan terciptanya budaya organisasi yang baik setiap individu akan mengikatkan dirinya dalam nilai-nilai, aturan-aturan, kebijakan prosedur dalam setiap tingkah lakunya untuk menjalankannya sebagai bagian dari aturan organisasi. Gaya kepemimpinan kepala sekolah dapat mempengaruhi empati guru dimaksudkan bahwa dengan kepemimpinan kepala sekolah maka dapat memberikan layanan bantuan kepada guru untuk memperbaiki kualitas, inovasi, kreativitas pada saat guru kesulitan dalam proses belajar mengajar. Hal ini sesuai dengan pendapat Yukl (2009: 5) menyatakan bahwa esensi dari kepemimpinan transformasional adalah memperdayakan para pengikutnya untuk berkarya, berkinerja secara efektif dengan membangun komitmen mereka terhadap berkembangnya inovasi dan kreativitas. Gaya kepemimpinan dapat memengaruhi motivasi guru agar mencapai tujuan dalam keberhasilan pendidikan memberikan kesempatan kepada guru untuk berprestasi, hal ini sesuai dengan pendapat Danim 2004: 139) bahwa sebagai pimpinan maka tugas kepala sekolah adalah menyatupadukan orang-orang yang berbeda-beda, memotivasinya dan memberikan inspirasi serta mendorong orang-orang yang di pimpinnya untuk bekerja secara efisien seefektif mungkin serta mengusahakan orang-orang yang di pimpinnya itu dapat menyesuaikan dengan perubahan situasi.

Pengaruh empati terhadap budaya organisasi berpengaruh signifikan dengan nilai koefisien jalurnya yang signifikan yakni $p_{\mathrm{y} 2}=0,258$, hal ini menunjukkan bahwa sikap empati dapat memberikan konstribusi perilaku terhadap peningkatan nilai budaya organisasi. Pengaruh motivasi terhadap budaya organisasi berpengaruh signifikan dengan nilai koefisien jalurnya yang signifikan yakni $\mathrm{p}_{\mathrm{y} 3}=0,305$, hal ini menunjukkan bahwa motivasi dapat memberikan konstribusi sikap dan perilaku terhadap peningkatan nilai budaya organisasi. Dengan demikian dapat dijelaskan koefisen jalur pengaruh empati kepala sekolah terhadap budaya organisasi signifikan dan pengaruh motivasi berprestasi signifikan terhadap perilaku budaya organisasi guru maka dapat pula dikatakan bahwa empati kepala sekolah memberikan konstribusi positif secara langsung pada peningkatan perilaku budaya organisasi.

Hal di atas sejalan dengan pendapat Jenifer M. George \& Greath R. Jones (2006: 535) Budaya organisasi adalah sekumpulan nilai, aturan dan norma yang mempengaruhi cara pegawai berpikir, merasakan dan berprilaku satu sama lainnya dan terhadap orang lain, di dalam dan diluar efektivitas organisasi.

\section{PENUTUP}

Simpulan. Terdapat pengaruh langsung positif gaya kepemimpinan, empati, motivasi terhadap terhadap budaya organisasi dan terdapat pengaruh langsung gaya kepemimpinan terhadap empati dan motivasi. 
Implikasi. Implikasi hasil penelitian sesuai dengan konsep pengaruh gaya kepemimpinan empati, motivasi terhadap terhadap perbaikan dan perubahan budaya organisasi kearah yang lebih baik. (1) Adanya pembinaan karakter leadership agar dapat melaksaknakan tugasnya lebih optimal. (2) Adanya perbaikan komunikasi yang dapat menciptakan hubungan kondusif antara kepala sekolah dan guru agar layanan bantuan guru dapat terpenuhi dengan baik sehingga guru dapat lebih kreatif dan inovatif. Ketiga: memberi masukan, mendorong dan memberi peluang kepada kepala sekolah untuk meningkatkan kemampuannya sesuai dengan harapan dan keinginannya dalam melaksanakan tugas sesuai dengan mekasnisme dan aturan yang berlaku.

Saran. Beberapa saran sebagai masukan adalah sebagai berikut: (1) kepala sekolah dapat menciptakan budaya organisasi yang baik melalui gaya kepemimpinan, empati dan motivasi; (2) kepala sekolah dapat meningkatkan kepemimpinannya dalam melaksanakan tanggungjawabnya, aturan dengan lebih baik; (3) Kepala sekolah dapat memfasilitasi guru dan karyawannya agar dapat mengikuti pelatihan-palitihan agar dapat memberikan nilai yang baik dalam organisasi.

\section{DAFTRA RUJUKAN}

Agus Efendi dalam Djafri.N. (2014) Manajemen Kecerdasan Emosi untuk Kepala sekolah. Ideas Publishing, Gorontalo.

Andrian Gostick dan Elton Chester, (2010) The Orange Revolution: How One Great team can Transform an Entire Organization.

Batson dalam Franzoi.L, (2006). Social Psychology. New York, McGraw Hill.Companies. Inc.

Brahmasari.I.A. dan Suprayetno. A. Pengaruh Motivasi Kerja, Kepemimpinan dan Budaya Organisasi terhadap Kepuasan Kerja KAryawan serta Dampaknya pada Kinerja Perusahaan (Studi Kasus pada PT Pei Hai International Wiratma Indonesia). Jurnal Manajemen dan Kewirausahaan Vol.10 (2) pp. 124-135. http://cpanel.petra.ac.id/ejournal/index.php/man/article/viewFile/17039/17003, diunduh Januari 2015

Colcuitt, Jason, Le Pine, Jeffery A dan Wesson, (2009) Goal Path. Mc Graw-Hill

Casio,Wayne F. (2008) Managing Human Resources. USA: McGraw Hill, Alih Bahasa Ayudia.

Danim, Sudarman, (2004) Motivasi Kepemimpinan dan Gaya Kelompok. Penerbit Rineka Cipta.

Franzoi S.L., (2003) Social Psychology. $3^{\text {rd }}$ edition. McGraw Hill Company.

George Jenifer $\mathrm{M}$ and Garet $\mathrm{R}$ Jones, (2006) Understanding and Managing Organizational Behavior. Sydney: Wesley Publishing Co, Ins,

George Jenifer $\mathrm{M}$ and Garet $\mathrm{R}$ Jones, (2006) Understanding and Managing Organizational Behavior. Sydney: Wesley Publishing Co, Ins.

Honey dalam Baron \& Byrne., (2005) Psikologi sosial. Alih Bahasa: Ratna Djuwita. Jakarta: Erlangga.

Herabudin., (2009) Administrasi dan Supervisi Pendidikan, Bandung, Pustaka Setia.

Ivanchevich, Konopaske, and Matteson., (2008) Organizational Behavior and Management, $8^{\text {th }}$ edition. New york: Mc Graw-Hill. 
Lussier, Robert N., (2009) Management Fundamental. USA. South Western.

McShane, Mary Ann Von Glinow, (2007) Organizational Behavior. (Essensials). Mc Graw-Hill Irwin.

Mullins Lauriens J., (2005) Manajement and Organizational Behaviour.Seventh Edition.Prentice Hall Financial Times.

Mulyasa, (2002) Manajemen Berbasis Sekolah Bandung: Remaja Rosdakarya.

Morgan E. James, (2009) Administrative and Supervisory Management, Englewood: Prentice-Hall, Inc, N.J.,

Newstrom, John W., (2007) Organizational Behavior, New York, McGraw Hill.

Nugraha, G., Astuti, E.S. dan Hakam, M.S. Pengaruh Insentif Finansial dan Insentif Non Finansial terhadap Motivasi dan Semangat Kerja Karyawan (Studi pada Karyawan PT Bank Negara Indonesia. Persero, TBK. Kantor Cabang Utama Madura). Jurnal $\begin{array}{lllllll}\text { Administrasi Bisnis } & \text { (JAB). } & \text { Vol. } & 6 & \text { (2) } & \text { pp. } & 1-7,\end{array}$ http://administrasibisnis.strudentjournal.ub.ac.id/index.php/jab/article/view/283, (diunduh Januari 2015)

Permen Diknas No. 13 Tahun 2007

Robbins, P.Stephen, \& Timothy A. Judge., (2009) Organizational Behavior $13^{\text {th }}$ Edition New Jersey: Pearson Education International, Prentice-Hall, Inc.

House, Robert J, Mitchell Terence R., (2003) "Path-Goal Theory of Leadership" Journal of Contemporary Business, Autumn.

Robert Tannenbaum dan Warren H. Schmidt, 1958 dalam Thoha Miftah (2002) Kepemimpinan dalam Manajemen Jakarta: RajaGrafindo Persada.

Utami Susiati Purwaning, (2014) "Hubungan antara Kecerdasan Emosi dan Budaya Organisasi dengan Gaya Kepemimpinan Supervisi Produksi di Pt. Faber Castell Indonesia”. Jurnal Ilmiah WIDYA. Vol.2, hal. 25-32. Nomor 1 Maret-April.

Rivai, Veithzal., (2003) Kepemimpinan Dan Perilaku Organisasi. Jakarta: Raja Grafindo.

Yukl.G.A., (2009) Power and the interpersonal influence of leaders.In Tjovold. D. and Van Knippenberg, B. (Eds) Power and interdependence inorganizations. Cambridge University Press. 